International Journal of Education (IJE), Vol. 3, No. 3, September 2015

\title{
PAHLAVI'S THE PIONEERS OF EDUCATION IN IRAN: A STUDY OF REZA SHAH
}

\author{
Prof. G. N. Khaki ${ }^{1}$ \\ Mohd Altaf Bhat ${ }^{2}$ \\ ${ }^{1}$ Professor, Director, Centre of Central Asian Studies, University of Kashmir, J and K, \\ India \\ ${ }^{2}$ Research Scholar, Centre of Central Asian Studies, University of Kashmir
}

\begin{abstract}
From the dawn of Iranian history, education and learning have been revered and preferred. In the $20^{\text {th }}$ century the tradition of learning has been put forward by the enlightened rule of the Pahlavi's father and son. Reza shah (1925-41) the founder of the Pahlavi dynasty believed that the expansion of modern education was a pre-requisite for social and political progress. He wants to make education a corner stone in his nationalist program. He considered education a single most important factor in promoting both the well being of the individual and the progress of the country and is the cure for all that is wrong with the people and the country. During this period a large number of elementary and secondary schools were established in Tehran and other major cities. Education received attention from all social classes. The purpose of the present paper is to examine the role of Reza shah Pahlavi in the development of education based on the modern curricula.
\end{abstract}

KEY WORDS: Pahlavi, education, Reza shah, curriculum, Maktab

\section{INTRODUCTION}

Iran is well known as one of the ancient seats of learning; colleges, seminaries and old fashioned schools with their picturesque architecture are scattered all over the country. Under the Qajars illiteracy was one of the striking features of Iran. The mass of the population was illiterate at the time of the establishment of the Pahalvi dynasty. The fight against the illiteracy was one of the most extreme urgency. Considering that Reza shah thought to set up a comprehensive system of state education based on modern curricula. He wanted to create an educated and informed population. The pahalvi regime devised a standardised and uniform school curriculum for both private and public schools in order to create a strong centralised government. Reza shah thought that education can only consolidate his authority for a long time. Since the 1920s both private and public education has been expanding systematically. The traditional elementary school system, the Maktab, began to give way to secular education in the late $19^{\text {th }}$ century. ${ }^{3} \mathrm{Up}$ to the end of the $19^{\text {th }}$ century the establishment of new and foreign schools was in the hands of foreigners. But significant progress has been made during the period of Reza shah.

\footnotetext{
1 Professor, Director, centre of central Asian studies, university of Kashmir, J and k, India

2 Research scholar, centre of central Asian studies, university of Kashmir

3 Arasteh Reza, Education and social awakening in Iran 1850- 1968, Leiden, E. J. Brill, 1969, p 69
}

DOI : 10.5121/ije.2015.3305 


\section{Development of education from 1925-1941}

The Education has always had a special significance in Iranian theology and culture since ancient times. Before the constitutional revolution, education was largely traditional with maktabas (village schools) and madrasas (theological schools) being at the base of the educational system. Rich nobleman and wealthy merchants for philanthropic purposes and heavenly reward constructed mosques, maktabas, madrasas and bestowed endowments for their upkeep and maintenance. The constitution revolution of 1906 paved the way for social and cultural changes, numerous clubs and associations were sprang up, private initiative contributed to the creation of a large number of modern schools in all the big cities of Iran. The state has definitely taken education in hand. Hundreds of modern schools were established in small towns and villages. Girls education had been neglected till then, now were given due consideration, and in all towns, small or large schools were opened for them. Isa khan sadiq a known educationist and minister writes that in 1922-23 there were 612 schools in whole Persia, while in 1928-29 the number of schools reached up to 3,283 . The numbers of graduates from schools of all levels were:

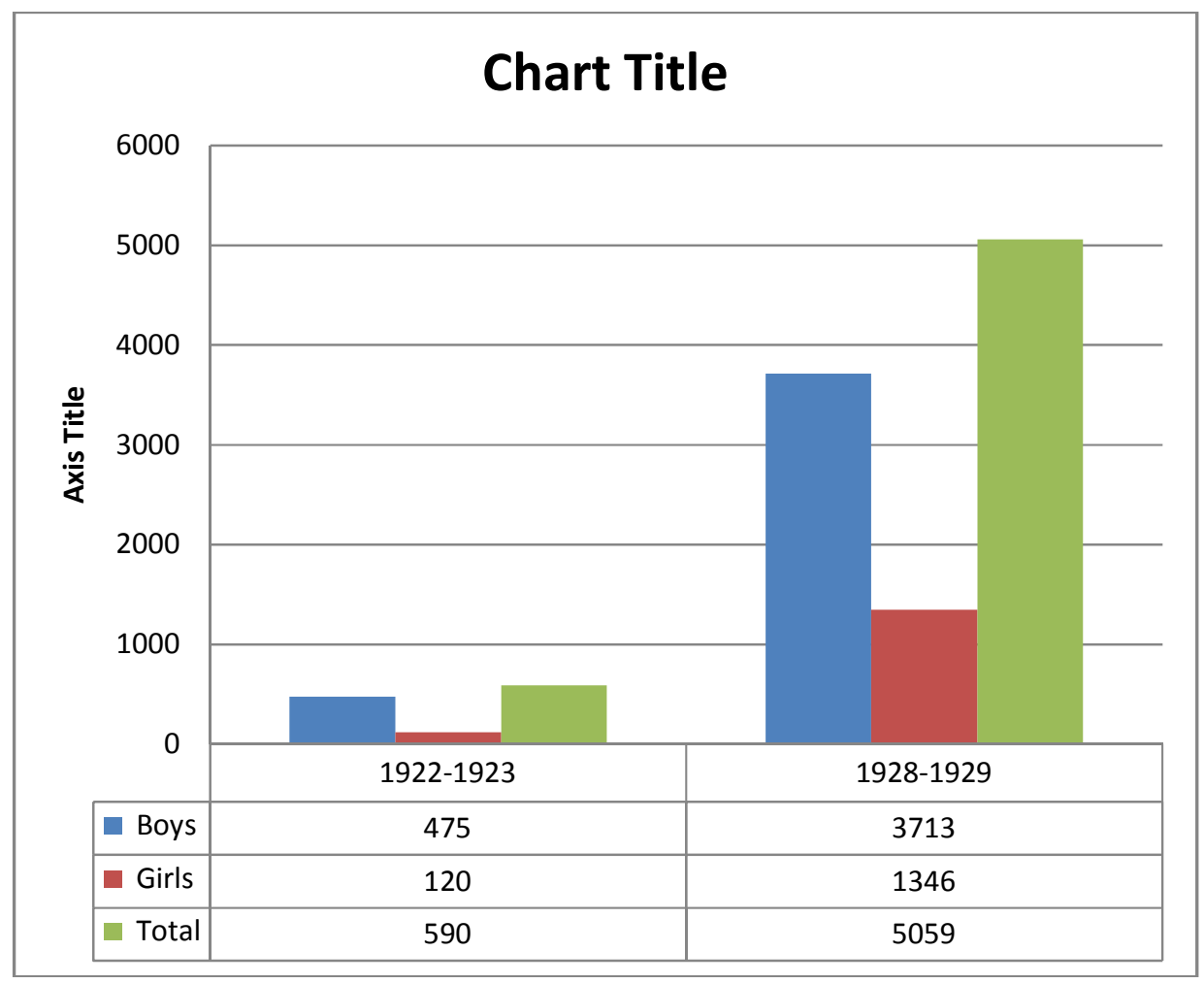

The percentage of girls to boys graduating was 25 in 1922-23 and 36 in 1928-29. In 1928-29 the enrolment of girls in schools was thirty percent of the number of boys. ${ }^{4}$ From 1928 onwards, 100

\footnotetext{
${ }^{4}$ Sadiq Issa khan, Modern Persia and Her educational system, Bureau of publications teachers college Columbia university New York, 1931, p 28,
} 
top secondary school students were sent annually to Europe, on bursaries, for a university education in the fields of medicine, engineering, dentistry and agriculture. Nine tenth $s$ of students went to France. The strongest element in Persian education is religion. From the time immemorial, education in Persia has been associated with religion and has been of a religious character. When Persia was conquered by the Arabs, in the middle of $7^{\text {th }}$ century, the traditions of the influence of religion on education remain stronger than ever. Now the only person who had mastered the Arabic or celestial vernacular and who understood the theology of Islam could properly teach and educate. Hence from the very beginning education was considered to be the monopoly of the ulema or clergy. Religion was the core of the educational program. ${ }^{5}$ In these maktabas traditional curriculum was followed such as; reading and writing, calligraphy, Arabic grammar and a lot of rote learning involving the memorization of passages from the Quran, verses of poetry etc. secondary education was carried on mainly through the services of private tutors. The only exception to this general picture was the madrasas, which were primarily theological seminaries. The maktabas and madrasas, were kept going solely by private donations and vaqf funds. The intellectuals criticised the traditional religious schooling system as stagnant and incapable of facing up to the challenge of the times. When Reza shah became the king of Iran, without delay he began to convert Iran's backward school system to western pattern. His first move was to wrest control of the schools from the clergy and, more broadly, to curb their influence. He devised an ingenious way to counter superstition and misuse of the clerical position; together with a group of enlightened loyal Mullahs. ${ }^{6}$ Reza shah was not concerned with conducting an ideological campaign against Islam but with fully establishing his monopoly of power. This implied reducing the influence of the ulema in all spheres of life and confining them to matters of faith and ritual. In fact, he wanted, religion to take a place similar to that customary in the Christian west at the time. To achieve this goal, the shah pinned his hopes on education. This helped him in reducing the number of maktaba and madrasa students. The government now deliberately worked to limit the maktabas and to subordinate them to the ministry of education.

The shah and his courtiers expanded the new school system, the population of the schools increased (including girls), and new branches of schooling i.e., vocational schools and universities were established. A minister of education with wide powers was appointed for the first time to run this department. Some separate schools for boys and girls were opened. This new education brings the country closer to the western ways. Every year some students were sending to Europe on government expenses. Westernization was the pivotal to the despatch of students to Europe. Reza shah told them that the purpose of sending them abroad at public expense was not only for them to acquire $\mathrm{Ilm}$, (knowledge) but also to acquaint them with western culture. ${ }^{7}$ During the reign of Reza shah the country's leading educationists and its politicians were united in their appreciation and in their conviction that it could produce rapid advances in the nation. Reza shah thought of education as the most potent force for Iran's cohesion as a nation, a force simultaneously capable of blunting supranational loyalties to Islam. All the education developed under Reza shah such as; elementary, secondary, tertiary or higher education, teacher education, adult education, special education etc. He created a government supported school system. The government also sponsored the creation of, first, boy scouts and then girl scouts, and some modern initiatives in sports and the arts, social welfare, including public health and hospitals.

Department of public education was set up within the ministry of education, then it assumed the supervision of elementary, secondary and adult education, including traditional schooling; it

\footnotetext{
${ }^{5}$ Ibid, pp 32-33

${ }^{6}$ Lenczowski George, Iran under the Pahalvis, Hoover institution press Stanford university, 1978, p 305306

${ }^{7}$ Menashri David, Education and the making of modern Iran, Cornell University Press Ithaca And London, 1992, pp 100- 105, Moulvi A. M, Modern Iran, Shah Bahram printing press clare road, Byculla Bombay, 1938, p 180
} 
directed teacher recruitment, developed text books and collected statistical data. The ministry also held tri-monthly examinations for all students. In 1935 the ministry of education issued certain regulations listing the specific days for examinations and the conditions under which pupils could be promoted from one class to another. ${ }^{8}$ In the 1920s and 1930s a national system of secondary education was established in Persia. More than 300 modern schools were founded in Tehran and provincial towns, the enrolment reached about 27,000 students in 1941. It was the period of Reza shah when the education saw important advances. The government for the first time put a regular and increasing share of taxes into education, so that educational expenses rose from 100,000 dollars in 1925 to $12-13$ million dollars in 1940. Still less than 10 percent of the population received any elementary education and for secondary education the figure was under one percent. Modern sciences and other modern subjects were introduced in the curriculum, laying he basis for a continued modernization of society official nationalism propagated an emphasis on Iranian history and literature, with stress on the pre- Islamic empires and de-emphasis of Islam. A uniform syllabus was prepared for elementary and secondary schools (for boys and girls) and was made mandatory for all schools. The graduates of all elementary, intermediate and high schools were required to take final examinations set by the ministry. Private schools were subordinated to the ministry and obliged to follow the official program. All schools including foreign ones were made to teach in Persian. Religious education declined, sons of the ulema tended increasingly to get secular education and jobs. ${ }^{9}$ The following table shows the numbers of madras's and Madrasa students in Iran 1924-1941.

\begin{tabular}{|l|l|l|}
\hline Year & No. Of Madrassas & Students/ Tullab \\
\hline $1924-25$ & 282 & 5,984 \\
\hline $1929-30$ & 315 & 4,598 \\
\hline $1939-40$ & 238 & 1,341 \\
\hline $1940-41$ & 250 & 784 \\
\hline
\end{tabular}

Source: Sharough Akhavi, p 187

The partial emancipation of Iranian women through education was one of the most important changes occurring during the period of Reza shah. Enrolments at elementary and secondary schools rose even faster for girls than for boys. The number of girls among the student body rose from 16.9 percent in 1922/3 to 28.0 percent in 1941/2. During these years, the aggregate school population grew by 7 times, but while the population of boys rose by 6.1 times, that of girls grew by 11.6 times, i.e. almost twice as fast. The share of the school population of women rose to 28 percent must be regarded as an important achievement. Reza shah himself saw a direct link between education for girls, the status of women, and the westernization process. The visit to turkey in 1934 became the main turning point in the policy of shah, after return from turkey he founded a women's association (kanun-e- banuvan). This association made an important contribution to the spread of education for girls. ${ }^{10}$ The changes in elite perception towards female participation in modern education are expressed in a 1929 exhortation to the government to draft a speedy educational plan for women. Suggestions even included sending women to Europe as part of the studies, so that they might be able to teach at women's schools. In the 1930,s female education gained further momentum as part of growing public and private attention to the furtherance of women's participation. Mixed schools were opened in Tehran as well as in the

\footnotetext{
8 Arasteh Reza, Education and social awakening in Iran 1850- 1968, Leiden, E. J. Brill, 1969, pp 76-78

9 Nikki R Keddie, Modern Iran: Roots and results of revolution, Yale University press 2006, p 99

${ }^{10}$ Menashri David, Education and the making of modern Iran, Cornell University Press ithaca And London, 1992, pp 108- 11o
} 
provinces, and plans were announced for the opening of mixed elementary schools throughout the country. Higher council of education approved a proposal that allowed women who had completed their eleven years of preparatory education to enter a special class of teachers college of Tehran in preparation for higher education. Tehran University was opened for women also. ${ }^{11}$ More women were admitted in the educational institutions. These efforts made to improve women's education, led to a considerable increase in the number of women in the nation's schools. In the 1930's, for the first time in Iranian history, women were the beneficiaries of major state reform introduced by Reza shah Pahlavi. The Pahlavi state as opposed to the preceding Qajar dynasty was assumed to be an alloy of women reforms. Women made their entrance into factory work, teaching and nursing etc. In 1936 women were ordered to unveil and dress in western style clothing. The Reza shah period has been praised often as an era of reform and dramatic social change. ${ }^{12}$ In 1936 the government undertook an adult education project. Adult classes were to be inaugurated in all public schools; they were to be held three evenings a week in two shifts, and no tuition fee was to be charged. In the year 1936/7, there were some 1500 classes (operating in two shifts each), with 93,371 students. In 1937/8 there were 1700 classes with 124,233 students, and in 1938/9, there were 911720 classes with 137703 students. The success of the elementary adult education led to the opening of twenty two secondary schools for adults in 1937. ${ }^{13}$ Physical education also developed during this period the government initiated a national program of physical education as part of its compulsory educational act. The ministry of education was made responsible for introducing compulsory physical education in all schools. In this way the education supports the growth of civil society, and political stability and allowing people to learn about their rights and acquire the skills and knowledge necessary to exercise them. In spite of these gigantic activities on the part of the government, foreign institutions are also doing remarkably well.

\section{CONCLUSION}

After assuming the power in 1925 Reza shah introduced reforms and brought profound changes to the educational system. During the sixteen years of his leadership many schools, institutes of higher education, colleges and other similar institutes were setup. Enrolment level increased from elementary up to higher levels. Reza shah's policy of centralization made all schools subject to the regulations of the ministry of education. The centralized curriculum was introduced and the course of studies was fixed through the ministry, and free education was provided for primary level. The education department was reorganised on modern lines. The goal of secularizing the education system was achieved most effectively through the gradual domination of state schools in elementary education at the expense of traditional maktabas. The private schools run by various religious minorities were brought under state control. Important contribution was made in the field of women's education. Reza shah provided free education and employment opportunities to women. The interrelationship between education and national consciousness came out most strongly in the adult education project undertaken in 1936. Reza shah wants to make education an experimental and dynamic force in society. He viewed the educational system as a tool for mobilizing broad support for the regime and its policies.

\footnotetext{
${ }^{11}$ Cronin Stephanie, The making of modern Iran state and society under Reza shah, 1921-1941, Routledge tylor and Francis group 2005, pp 133-34

${ }_{12}$ Nikki R Keddie, Modern Iran: Roots and results of revolution, Yale University press 2006, p 100

${ }^{13}$ Menashri David, Education and the making of modern Iran, Cornell University Press Ithaca And London, 1992, pp 96-97
} 
International Journal of Education (IJE), Vol. 3, No. 3, September 2015

\section{BIBLIOGRAPHY}

[1] Arasteh, Reza (1969), Education and social awakening in Iran 1850- 1968, Leiden, E. J. Brill

[2] Menashri, David (1992), Education and the making of modern Iran, Cornell University press Ithaca and London.

[3] Sadiq, Isa khan (1931), Modern Persia and her educational system, Bureau of publications teachers college Columbia University New York city.

[4] Lenczowski, George (1978), Iran under the Pahlavi's, Hoover university press stanford california

[5] Akhavi, shahrough (1980), Religion and politics in contemporary Iran: clergy state relations in the Pahlavi period, state university of New York press Albany

[6] Hiro, Dilip (1985), Iran under the Ayatullahas, Routledge and Kegan Paul London and New York

[7] Abrahamian, Ervand (2008), A history of Modern Iran, Cambridge university press

[8] Fischer, Michael (1980), Iran from Religious dispute to revolution, Cambridge, mass

[9] Keddie, Nikki (2006), Modern Iran: Roots and results of revolution, Yale university press

[10] Abrahamian, Ervand (1982), Iran between two revolutions, Princeton university press, New jersey

[11] Cronin, stephanie (2005), The making of modern Iran state and society under Reza shah, 1921-1941, Routledge tylor and Francis group

[12] Moulvi A. M (1938), Modern Iran, Shah Bahram printing press clare road, Byculla Bombay 